\title{
Evaluation and Identification of Bacterial Diseases of Tomatoes by the Method of Flash-PCR
}

\author{
Gulnaz Kamirdinovna Nizamdinova ${ }^{1}$, Abay Orazovich Sagitov², \\ Julian James Smith ${ }^{3}$, Temirjan Erkasovich Aitbayev ${ }^{4}$ \\ and Serjan Bahytovich Amanov
}

${ }^{1}$ Kazakh National Agrarian University, Kazakhstan, 050010, Almaty, Abai Avenue, 8

${ }^{2}$ Kazakh Research Institute for Plant Protection and Quarantine.

${ }^{3}$ The Food and Environment Research Agency (FERA) Julian.

${ }^{4}$ Kazakh Research Institute of Potato and Vegetable Growing

${ }^{5}$ Kazakh Research Institute for Plant Protection and Quarantine

http://dx.doi.org/10.13005/bbra/2120

(Received: 01 April 2016; accepted: 14 May 2016)

In 2014-2015 was conducted a monitoring aimed for clarifying the species composition of bacterial diseases of tomato in the South East of the Republic of Kazakhstan. The identification of causative agents of bacterial diseases of tomato was carried out in the laboratory of the Kazakh Research Institute of Protection and Quarantine of Plants by using the method of molecular-genetic analysis - FLASH - PCR. As a result of research it was reviled a species composition of bacterial diseases of tomato, as well as preventive measures for the elimination of bacterial infection in the seeds.

Keywords: Flash PCR, heat treatment, plant pathogenic bacteria, biological products.

Tomato fruits are widely used fresh and are also for canning and processing. The total area of this crop in the Republic of Kazakhstan is about 20 thousands of hectares. The largest area that belongs to this culture is in the South of Kazakhstan - South Kazakhstan region, Almaty region and Zhambyl region. Some of the reasons of low yield of tomato are hitting and a wide range of diseases of a fungal, bacterial and viral etiology. According to the research of Kazenas L. D. (1974) 28 tomato diseases were registered in Kazakhstan ${ }^{1}$.

Despite of a widespread and a substantial harmfulness of bacterial diseases of tomatoes, the comprehensive and in-depth studies of the bacterial diseases of this culture were not carried out in Kazakhstan for more than 40 years, was not evaluated their species composition and were not developed the protective measures against these

\footnotetext{
* To whom all correspondence should be addressed.
}

diseases. In this regard, the first aim of this work is the diagnostics of bacterial diseases of tomato by using the PCR in the FLASH format, and the second aim is to carry out preventive measures for disinfection of seeds.

Technique

The objects of a research were plants and fruits of the tomato affected by bacteriosis and the phytopathogenic bacteria isolated in pure cultures. Species composition and distribution of bacterial diseases were established during route inspections of vegetable farms in the South East of Kazakhstan in accordance with the standard phytopathological methods ${ }^{2,3}$. Initially, the pathogenicity was determined on the indicator plants of potted geranium by the infectious-infiltration method of Klement A., Matyshevskaya M. S. ${ }^{4}$. Further on, the selected strains of bacteria were tested for the pathogenicity on plants they were isolated from, later on were obtained a similar symptom of the bacterial diseases of tomato ${ }^{5}$. 
The samples were analysed by isolating the pathogen in pure culture for the further identification in the FLASH format. The DNA isolation was carried out on the amplifier "Terzic" using diagnostic systems that were developed on the basic composition of the reaction mixture and amplification.

The principle of the device consists in the registration of fluorescent radiation produced in the reaction mixture at illumination of the sample by the exciting light source. Registration is performed sequentially for each of the glass tubes during its positioning relative to the optical unit using a stepping motor.

The test systems are simple and convenient for mass analysis and provide with a high sensitivity and specificity determining the detected pathogens. The test systems for the above mentioned pathogens in a format of FLASHPCR were developed for the very first time and have no analogues in Kazakhstan and abroad. In all test systems are used the original primers and probes. For the first time it was demonstrated that the probe of a "molecular beacon" type is destroyed by an enzyme with 5'-3' exonucleoside activity during chain elongation of DNA during $\mathrm{PCR}^{6}$.

The program of amplification included the following steps: $94^{\circ} \mathrm{C}-1 \mathrm{~min} 30 \mathrm{sec} ; 1$ cycle, $94^{\circ} \mathrm{C}$ $20 \mathrm{sec}, 64^{\circ} \mathrm{C} / 67^{\circ} \mathrm{C}-5$ sec, 5 cycles; $94^{\circ} \mathrm{C}-1 \mathrm{sec}$, $64^{\circ} \mathrm{C} / 67^{\circ} \mathrm{C}-5 \mathrm{sec}, 40$ cycles. Reaction mixture for amplification consists of $35 \mu \mathrm{l}$ : $3.5 \mu \mathrm{l} 10 \mathrm{x}$ buffer (750 mM Tris-HCl, pH 8.8, 200 mM ammonium sulfate, $0.1 \%$ Twin-20), $1 \mathrm{mM}$ of each dNTP, 1 ìM of primers, $0.1-0.2 \mu \mathrm{M}$ of probes, and 2.5 units of Taq-polymerase, $5 \mu \mathrm{l}$ of the DNA solution and 0.5 $\mu \mathrm{l}$ of a solution of the plasmid for the internal control.

\section{The method is the intermediate between the classical and the real-time PCRs}

The device registers the background fluorescence, which magnitude depends on: the properties of labeled probes; the concentration changes of individual components of the reaction mixture depending on the series, mode and duration of storage; used plastic; the characteristics of the recording equipment.

To control the reliability of the system was organized the internal control (IC).

In "K+" and " $\mathrm{K}$ " - are the control samples.
The result "+" - the presence of the desired pathogen in the sample. The result is "-" - the absence of the pathogen in the sample.

With the purpose of the preventive recovery of pathogenic infections in laboratory conditions were conducted series of experiments on the thermal disinfection of seeds of tomato. Were tested the following temperature regimes $70,75,80,85,90,95^{\circ} \mathrm{C}$, and a time of exposure - 2,4 , 8, 12, 16, 20, 24 hours. For evaluation of thermal treatment on sowing quality of seeds were used two parameters - the energy of germination and laboratory germination.

The estimation of sowing qualities of seeds was tested by germination of seeds in thermostat in moist chambers (Petri dishes with moist filter paper), 50 pieces, with the surface excess of 4 times. Germination energy was determined on the 5th, and laboratory germination on the 10th day by counting germinated seeds comparing with the total number?

After thermal treatment in order to increase the germination energy were tested preparations-stimulators of growth, such as Aspinal, Fitosporin, Zircon, HB-101 and EPIN extra, Mers, Fitolavin.

\section{RESULTS}

In 2014-2015 years was made a monitoring in Almaty and Zhambyl regions aimed for clarifying the species composition of bacterial diseases of tomato. Test systems for detection of pathogens of bacterial diseases of tomato were tested in the laboratory of the Kazakh Research Institute of Protection and Quarantine of Plants.

The level of fluorescence in a background test tubes were taken per unit, and the value of the specific signal and the signal of IC was calculated by the program in units of the background: signal HEX(IC) more than 2.5 was taken as positive (+); Fam signal (Specificity) more than 2.1 was recorded as positive (+), less than 1.75 - negative (-), and between 1.75 and 2,5 - questionable (?); when the values of signal "IC" and "Specificity" are less than 1.75 - the result was considered as unreliable. The names of the analyzed culture are given in the information about the samples, "K+" - positive control (DNA) of a diagnostic kit, "K-" - a sample of the last stage of DNA extraction. 
As a result of the PCR analysis by the method of FLASH, the following types of bacteria were identified:

In table 1 were tested strains under the numbers 20-32, were selected with signs of bacterial black spot. They showed a positive reaction against Xantomonas campestris.

In table 2, there are samples that were extracted from the symptoms of bacterial wilt, No. 115-116 have a low concentration of Fam coefficient, while " $\mathrm{K}+$ " indicates - 7.28. The performance of the IC is high enough. This suggests that in the presence of a specificity of primer it is important to work out the modes of amplification.

Table 3 shows the results of a bacterial cancer of tomato. All analyzed strains showed an aggressive form compared to the positive control.

Table 4 shows the results of watery rot of tomato fruits. All tested strains showed a positive reaction against Erwinia corotovora.

The results of the survey showed that the most wide spread tomato bacteriosis is a bacterial spot (Xantomonas campestris pv.

Table 1. The result of FLASH PCR diagnostic of bacterial black spot (Xanthomonas campestris pv. vesicatoria)

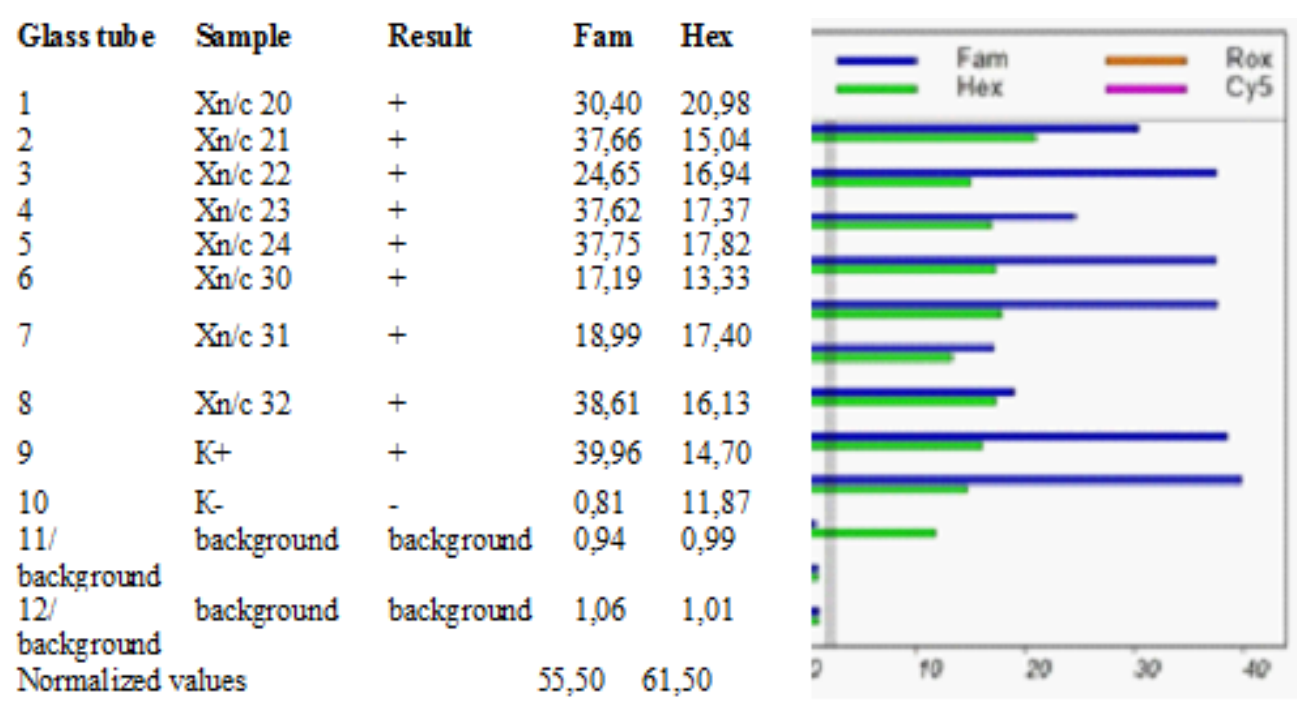

Table 2. The result of FLASH PCR diagnostic of bacterial wilt of tomato (Ralstonia solanacearum (E. F. Smith)Bergey)

$\begin{array}{lllll}\text { Glass tube } & \text { Sample } & \text { Result } & \text { Fam } & \text { Hex } \\ 1 & \mathrm{~K}+ & + & 7,28 & 27,97 \\ 2 & \mathrm{~K}- & - & 0,97 & 24,38 \\ 3 & \mathrm{R} / \mathrm{s} 97 & + & 4,18 & 24,25 \\ 4 & \mathrm{R} / \mathrm{s} 98 & + & 4,30 & 17,59 \\ 5 & \mathrm{R} / \mathrm{s} 99 & + & 5,41 & 22,96 \\ 6 & \mathrm{R} / \mathrm{s} 112 & + & 5,39 & 28,66 \\ 7 & \mathrm{R} / \mathrm{s} 113 & + & 13,90 & 28,14 \\ & \mathrm{R} / \mathrm{s} 114 & - & 1,48 & 19,10 \\ 8 & \mathrm{R} / \mathrm{s} 115 & + & 3,85 & 26,93 \\ 9 & \mathrm{R} / \mathrm{s} 116 & + & 2,99 & 26,71 \\ 10 & \text { background } & \text { background } & 0,99 & 0,96 \\ 11 / & & & \\ \text { background } & & \text { background } & 1,01 & 1,04 \\ 12 / & \text { background } & & & \\ \text { background } & & & 59,50 & 36,50 \\ \text { Normalized valves } & & & \end{array}$

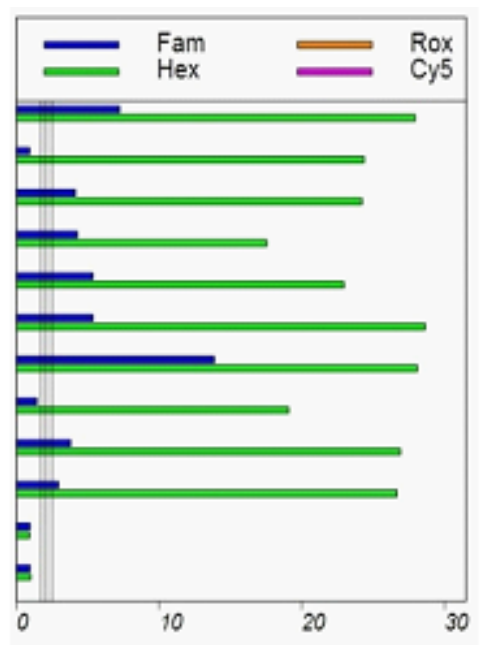


Vesicatoria) whose prevalence reached $32 \%$. The symptoms of the disease manifested on the cotyledons, leaves, petioles, stems and fruits in the form of small sunken brown spots of irregular shape, which rapidly increased in size, merged. The spots on fruits are black, convex and surrounded by a watery border. The damage of the disease is characterized with the reducing of assimilation surface, with inhibition of plants, with reducing yield and marketable quality of the fruit. Bacterial spot is the most common disease of tomato, some several researchers obtained the similar symptoms, which were confirmed by molecular genetic analyses ${ }^{8,9}$.
The significant damage to tomato was also made by the bacterial cancer of tomato during the years of the study (Clavibacter michiganensis subsp. michiganensis) with the distribution of $28 \%$. The first symptoms were observed in a month after transplanting into soil, in the budding phase the symptoms appear in the form of a slow fading. A characteristic feature of bacterial cancer of tomato was that the wilting of the leaves was originally shown on one side of the plant, while the other remained sometimes unaffected. On the cuts of the stem of the ill plant was observed darkening of the vessels. The affected fruits have changed their colour for a several times, were observed the lesions

Table 3. The result of FLASH PCR diagnostic of bacterial cancer of tomato (Clavibacter michiganensis subsp. michiganensis)

$\begin{array}{lllll}\text { Glass tube } & \text { Sample } & \text { Result } & \text { Fam } & \text { Hex } \\ 1 & \mathrm{C} 1 / \mathrm{m} 60 & + & 16.27 & 12.85 \\ 2 & \mathrm{C} / \mathrm{m} & + & 16.58 & 18.80 \\ 3 & \mathrm{C} / \mathrm{m} & + & 25.53 & 17.77 \\ 4 & \mathrm{C} / \mathrm{m} & + & 38.34 & 15.71 \\ 5 & \mathrm{C} / \mathrm{m} & + & 37.68 & 17.79 \\ 6 & \mathrm{C} / \mathrm{m} & + & 37.21 & 16.96 \\ 7 & \mathrm{C} / \mathrm{m} & + & 24.81 & 8.94 \\ 8 & \mathrm{C} / \mathrm{m} & + & 38.54 & 16.10 \\ 9 & \mathrm{~K}+ & + & 39.95 & 14.68 \\ 10 & \mathrm{~K}- & - & 0.81 & 11.87 \\ 11 / & \text { background } & \text { background } & 0,94 & 0,99 \\ \text { background } & & & & \\ 12 / & \text { background } & \text { background } & 1,06 & 1,01 \\ \text { background } & & & 55,50 & 61,50\end{array}$

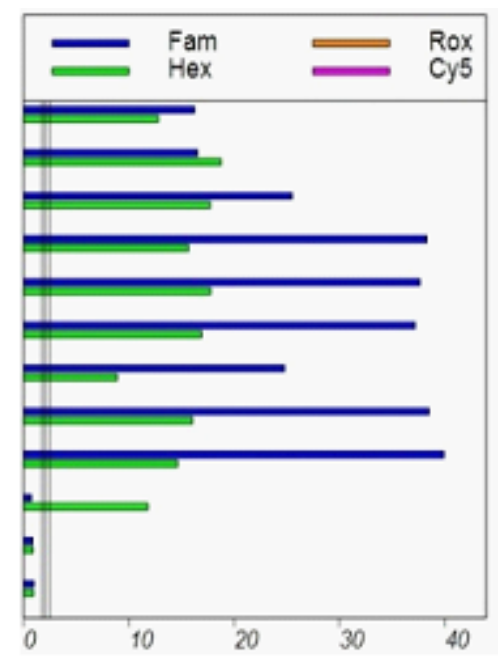

Table 4. The result of FLASH PCR diagnostic of watery rot of tomato (Erwinia carotovorum pv. carotovorum)

\begin{tabular}{|c|c|c|c|c|}
\hline Glass tube & Sample & Result & F am & Hex \\
\hline 1 & $\mathrm{E}_{\mathrm{r} / \mathrm{c}} 41$ & + & 9.00 & 17.32 \\
\hline 2 & $\mathrm{Er} / \mathrm{c} 42$ & + & 20.80 & 12.25 \\
\hline 3 & $\mathrm{E}_{\mathrm{r} / \mathrm{c}} 43$ & + & 13.78 & 10.00 \\
\hline 4 & $\mathrm{Er} / \mathrm{c} 44$ & + & 17.73 & 19.50 \\
\hline 5 & $\mathrm{Er} / \mathrm{c} 45$ & + & 8.46 & 20.25 \\
\hline 6 & $\mathrm{Er} / \mathrm{c} 46$ & + & 7.83 & 19.54 \\
\hline 7 & $\mathrm{Er} / \mathrm{c} 47$ & + & 18.83 & 19.68 \\
\hline 8 & $\mathrm{Er}_{\mathrm{r} / \mathrm{c}} 48$ & + & 13.02 & 13.18 \\
\hline 9 & $\mathrm{~K}+$ & + & 13.88 & 14.46 \\
\hline 10 & $\mathrm{~K}$ - & - & 0.90 & 12.16 \\
\hline & background & background & 0.95 & 1.00 \\
\hline $\begin{array}{l}\text { background } \\
12 / \\
\text { background }\end{array}$ & background & & 1.05 & 1.00 \\
\hline Normalized & alves & & 41.00 & 56.00 \\
\hline
\end{tabular}

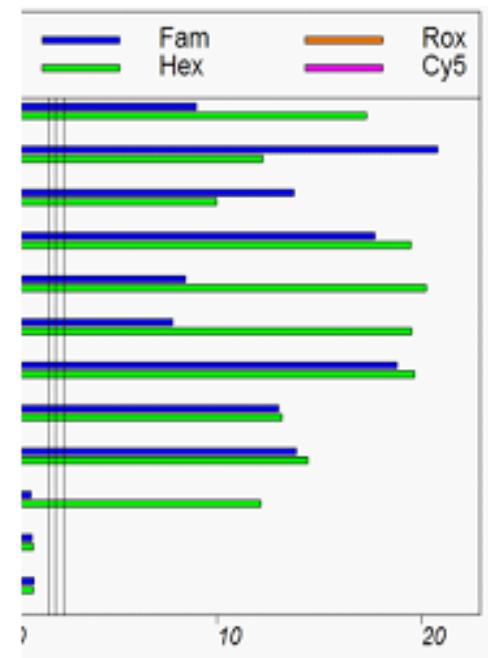


in the form of white spots with a dark center, resembling a birds eye. More clearly the symptoms of the fruit disease were observed by the end of the growing season.

With the influence of watery rot (Erwinia carotovorum pv. carotovorum), tissue of stems and fruit have softened and acquired a dark-brown color. Then moving by the stem they spread on the fruit, the destruction usually began with the peduncle, and by the end of vegetation the distribution reached $12 \%$. The main sources of infection are the infected vegetation residues. In addition, the bacterium is constantly present in the rhizosphere of many crops and weeds.

The examination also identified a bacterial wilt of tomato (Ralstonia solanacearum (E. F. Smith) Bergey) the prevalence was negligible, within $4 \%$. Were observed the following symptoms of the disease: a wilting of lower leaves, leading to the fading of the whole plant, and at the same time there was no yellowing (chlorosis) of the leaves. While cutting the stem, the cut oozed a gray slimy bacterial exudate.

\section{DISCUSSION}

In studies of some authors "dry thermal method" showed the possibility of its application on seeds of some field and vegetable crops for the destruction of their bacterial infections. I. I. Tanase [10] reports that the core necrosis of tomato is suppressed by the thermal disinfection of seeds at $80^{\circ} \mathrm{C}$ for 1 hour. L. D, Loginovskaya ${ }^{11}$ finds that thermal $\left(53^{\circ} \mathrm{C}\right.$ for $\left.30 \mathrm{~min}\right)$ disinfection ensures a high level of protection of tomato seed from agents of bacterial diseases.

Our experiments on thermal disinfection of seeds of tomato showed that the temperature regimes do not have the same effect on their sowing qualities. In all exposures a temperature of $70^{\circ} \mathrm{C}$ has no negative influence on the germination energy and on laboratory germination of seeds, do not significantly differs from a control. Germination ranges from $86 \%$ to $88 \%$, laboratory germination $-85-89 \%$. A deterioration of the sowing qualities of seeds is registered after 8 hours of exposure with a temperature of $75^{\circ} \mathrm{C}$, an energy of germination is $43-50 \%$, a laboratory germination 70-73\%. Starting with 800 Ñ and above a significant decries in these indicators is noted.

\section{CONCLUSION}

As a result of phytopathological analyses of affected samples with symptoms of bacterial diseases revealed that all organs of the tomatoes stood out phytopathogenic bacteria belonging to the genera Xantomonas, Ralstonia, Clavibàcter and Erwinia. At artificial contamination with these agents of indicator plants, similar symptoms manifest on the host plants.

In diagnostic with a method of Flash PCR, the fluorescent molecular genetic methods of diagnosis of the most important pathogens of tomato are developed. Was evaluated the primary data of their distribution in South-Eastern Kazakhstan. The results show that there are all technical possibilities for regular monitoring of tomato diseases with a real time PCR.

As a result of the thermal treatment, it was found that the optimal temperature without impairing the germination and laboratory germination of seeds is $70^{\circ} \mathrm{C}$ with the exposure time from 12 to 24 hours $^{10}$. After a thermal treatment the using of biological products improves both germination and germination of seeds. When the thermal treatment is accompanied with phytoproduct Akpinol, the germination achieves the level of $83.5 \%$, and in the case of its absence only $62.8 \%$. Similar results were shown also with the use of phytolavin and zircon.

\section{ACKNOWLEDGMENTS}

I express my gratitude for a candidate of biological sciences - Jaimurzina Alia Abdrakhimovna for the consultation and a help in the phytopathological analyses, as well as for the foreign consultants - Dr John Elphinstone and Dr Richard Thwaites for the training of molecular genetic methods for identification of bacterial diseases.

\section{REFERENCES}

1. Kazenas L.D., Diseases of cultural plants in Kazakhstan. Almaty, Kainar, 1974; 212-215 (in Russian).

2. Chumakov A.E. General methods in plant pathology. Moscow (in Russian), 1974.

3. Chumaevskay M.A. and Matveeva E.V. Methodological guide to plant pathogenic 
bacteria isolation and identification, 1986; 40. (in Russian).

4. Kiraly Z. et al., Methods in plant pathology. Moscow, 1976; 343 pp. (in Russian).

5. Punina, N.V. Occurrence of Xanthomonas campestris pv. raphani on tomato plants in Russian Federation / N.V. Punina, A.N. Ignatov, K.P. Kornev, E.V. Matveeva, V.A. Polityko, N.W. Schaad // ISHS, Acta Horticulturae. 2009; 287290.

6. Ryazantsev D.Y, Rebrikov D.V Drobyazin P.E, Zavriev S.K., Diagnosis of main plant pathogens of cucumber and tomato by polymerase chain reaction on FLASH format. Methodological guidelines. Moscow Research Institute of Phytopathology. 21-24pp.

7. Dzhaimurzina A.A. et al. Control methods for the cucumber bacteriosis. Authors certificate N 113087 (in Russian), 1984.
8. Janice LeBoeuf - OMAFRA; and ect. Bacterial Diseases of Tomato: Bacterial Spot, Bacterial Speck, Bacterial Canker, 2009.

9. Finetti Sialer M.M., Rosso L., Molecular detection in integrated pest and disease managemtnt. General Concepts in Integrated Pest and Disease Management. 2007; 305-28.

10. Tanase I.I. Masuri de prevenire si combatere a necrozarii bacteriene a maduvei (Pseudomonas corrugate) la tomatele cultivate in sera. Prod. veg. hort. 1989; 38(4): 10-12.

11. Loginovskaya L.D Primarily diagnosis of seeds. Protection and quarantine of plants. 1998. 3: P.24-25 (in Russian).

12. Gulnaz Nizamdinova, Abay Sagotov, Bacterial spot and bacterial speck of tomato in the Almaty district of Kazakhstan. Scientific works/ Agrarian University - Plovdiv, 2012; - P. 7-12. 